\title{
建築物のエネルギー消費性能の向上に関する法律の 一部を改正する法律について
}

国土交通省住宅局住宅生産課建築環境企画室

\section{1.はじめに}

我が国のエネルギー源は、その中心である化石燃料の 大半を輸入に頼るという根本的な脆弱性を抱えており、 エネルギーの安定的確保が常に大きな課題とされていま す。特に2011年 3 月11日に発生した東日本大震災以降、 エネルギー需給構造の安定化が不可欠となり、エネル ギーの安定的供給とともに省エネルギー対策の徹底が求 められています。こうした中、2015年 7 月、2030年度に おけるエネルギー需給構造のあるべき姿を示した長期エ ネルギー需給見通し（経済産業省）が策定され、さらに、 2018年 7 月に閣議決定された第 5 次エネルギー基本計画 の中で、その実現を目指すこととされています。長期エ ネルギー需給見通しにおいては、省エネルギー対策の見 通しとして、2030年度のエネルギー消費量を省エネル ギー対策前と比較して約 $13 \%$ 削減することが揭げられて います。

また、2015年12月に、温室効果ガス排出削減のための 国際的な枠組みである「パリ協定」が採択（2016年11月 発効）され、同協定を踏まえ、地球温暖化対策計画 （2016年 5 月閣議決定）において、長期エネルギー需給
見通しと整合的なものとして、2030年度の温室効果ガス 排出量を2013年度と比較して $26.0 \%$ 削減する中期目標が 掲げられています。（図 1)

このように、エネルギーの需給構造の安定化と地球温 暖化対策の両面から、省エネルギー対策の推進は不可欠 とされる中、地球温暖化対策計画等に基づく住宅・建築 物分野における2030年度の中期目標等の達成に向け、住 宅・建築物分野においては、2030年度のエネルギー消費 量を2013年度と比較して約 2 割削減することが求められ ており、住宅・建築物の省エネルギー性能（以下「省エ ネ性能」という。）の向上を図ることは喫緊の課題と なっています。

\section{2. 住宅・建築物の省エネ性能等に係る実態}

住宅・建築物の省エネ性能の向上を進めていくために は、規模・用途ごとの省エネ性能の実態等を踏まえ、実 効性の高い総合的な省エネ対策を進めていくことが必要 となりますが、建築物の規模・用途ごとの省エネ性能に 関する実態等は、以下のとおりとなっています。

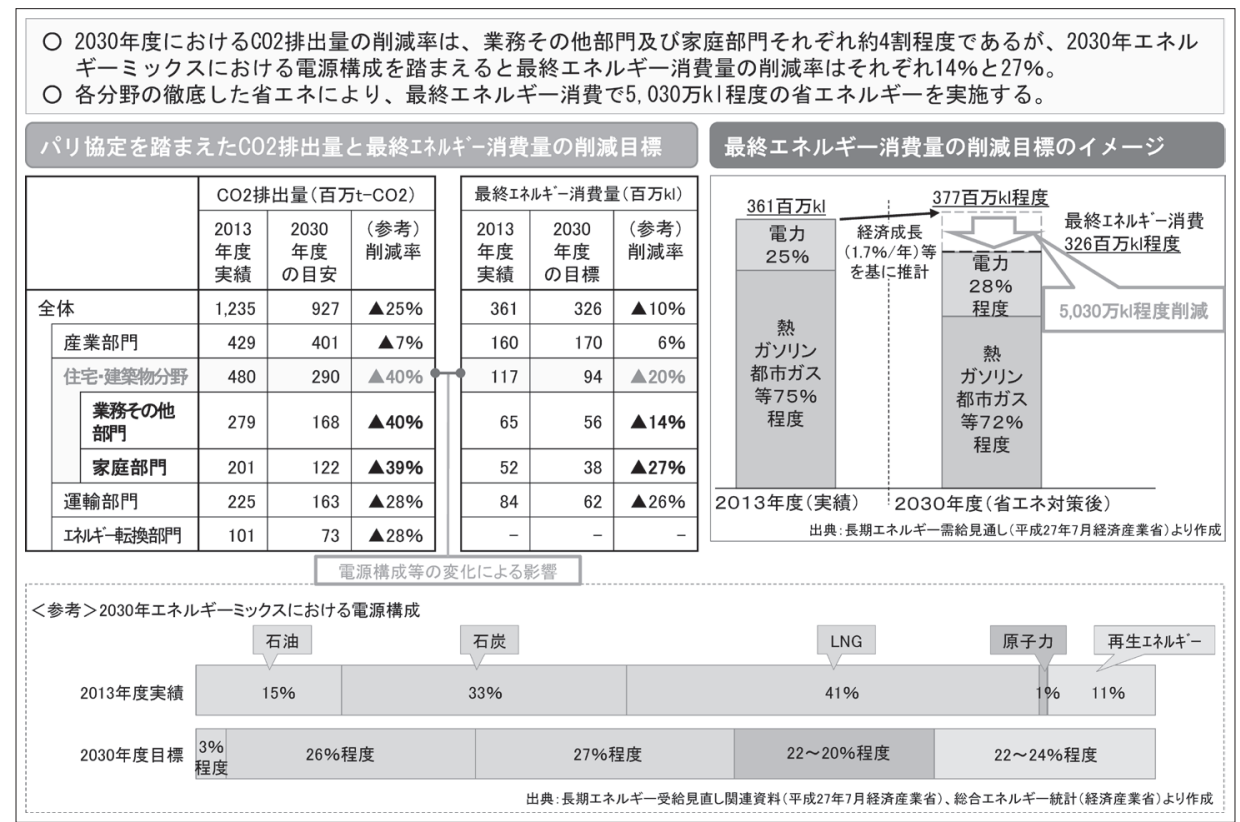

図 1 パリ協定を踏まえた地球温暖化対策計画におけるエネルギー削減目標 


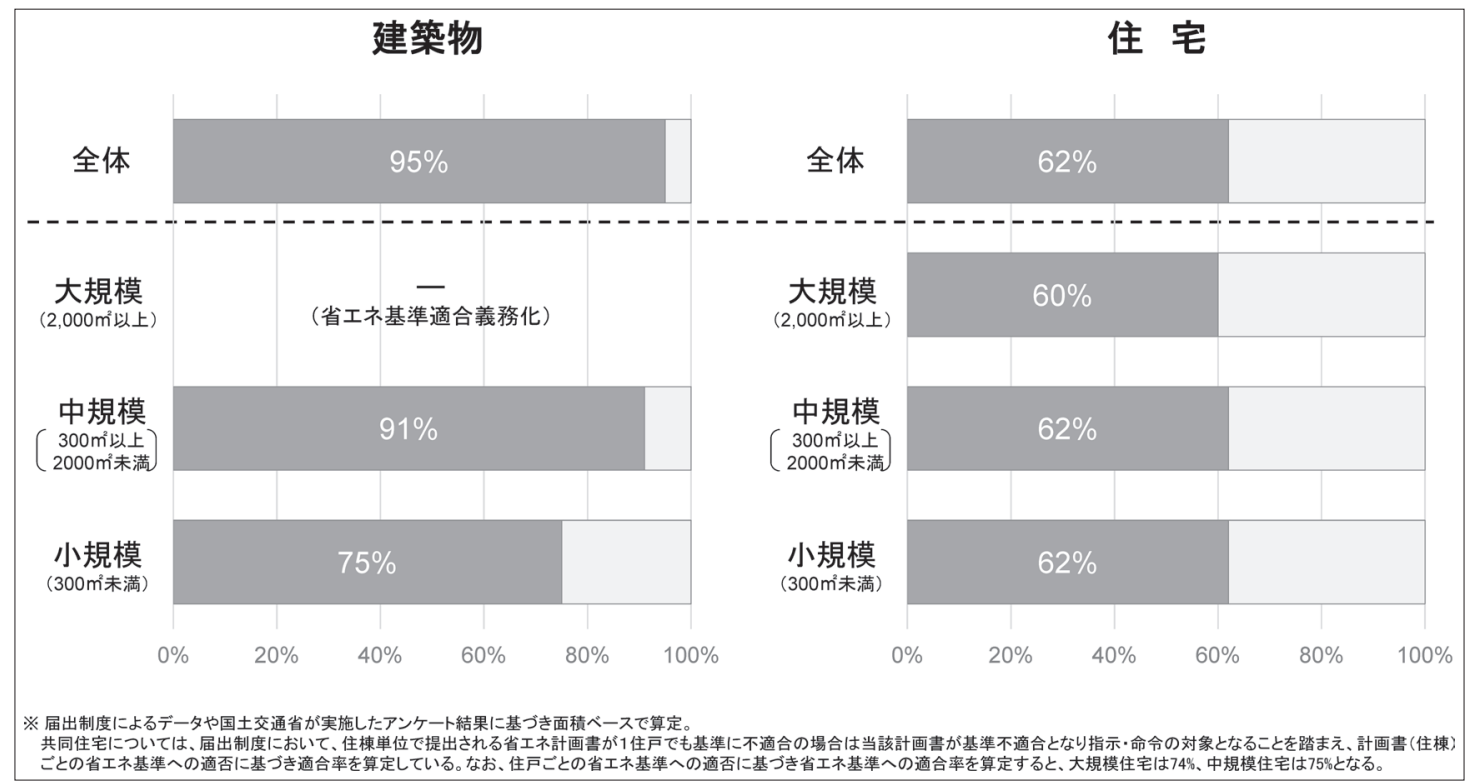

図 2 住宅・建築物の規模別の省エネ基準適合率（平成29年度）

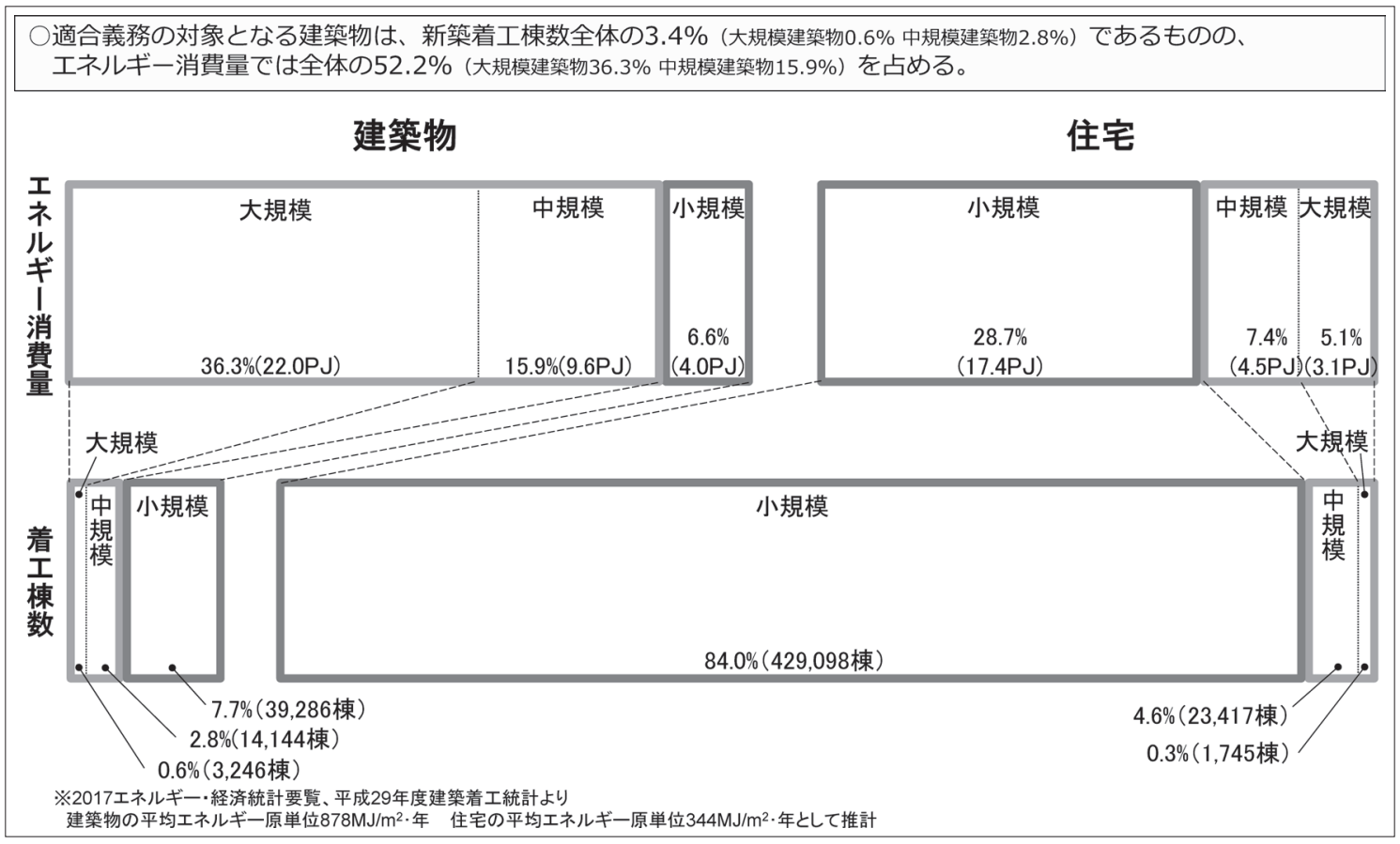

図 3 住宅・建築物の規模別のエネルギー消費量と着工棟数との関係

\section{【省エネ基準への適合率】}

2017年度における住宅・建築物の規模別の省エネ基準 への適合率は、図 2 のちおとなっており、中規模（延 ベ面積 $300 \mathrm{~m}^{2}$ 以上 $2,000 \mathrm{~m}^{2}$ 未満）建築物（住宅以外）は $91 \%$ と比較的高い水準にある一方で、住宅及び小規模 (延べ面積 $300 \mathrm{~m}^{2}$ 未満) 建築物（住宅以外）は60\% 75\%にとどまっています。

\section{【新築件数とエネルギー消費量】}

2017年度における新築件数とエネルギー消費量は、図 3 のとおりとなっており、大規模（延べ面積 $2,000 \mathrm{~m}^{2}$ 以 上）住宅、中規模住宅及び中規模建築物（住宅以外）は、 合計エネルギー消費量の全体に占める割合に比して新築 件数の全体に占める割合が小さい一方で、小規模住宅・
小規模建築物は、合計エネルギー消費量の全体に占める 割合に比して新築件数の全体に占める割合が非常に大き くなっています。

\section{【関連事業者の省エネ基準等への習熟状況】}

（公社）日本建築士会連合会が実施したアンケート調 査によると、小規模住宅の設計を担っている建築士事務 所のうち、省エネ計算が実施可能なものの割合は概ね $50 \%$ となっています。また、(一社) リビングアメニティ 協会が実施したアンケート調査によると、中小工務店の うち、省エネ計算が実施可能なものの割合は概ね $250 \%$ と なっており、規模が小さい工務店ほどその割合が低く なっています。 


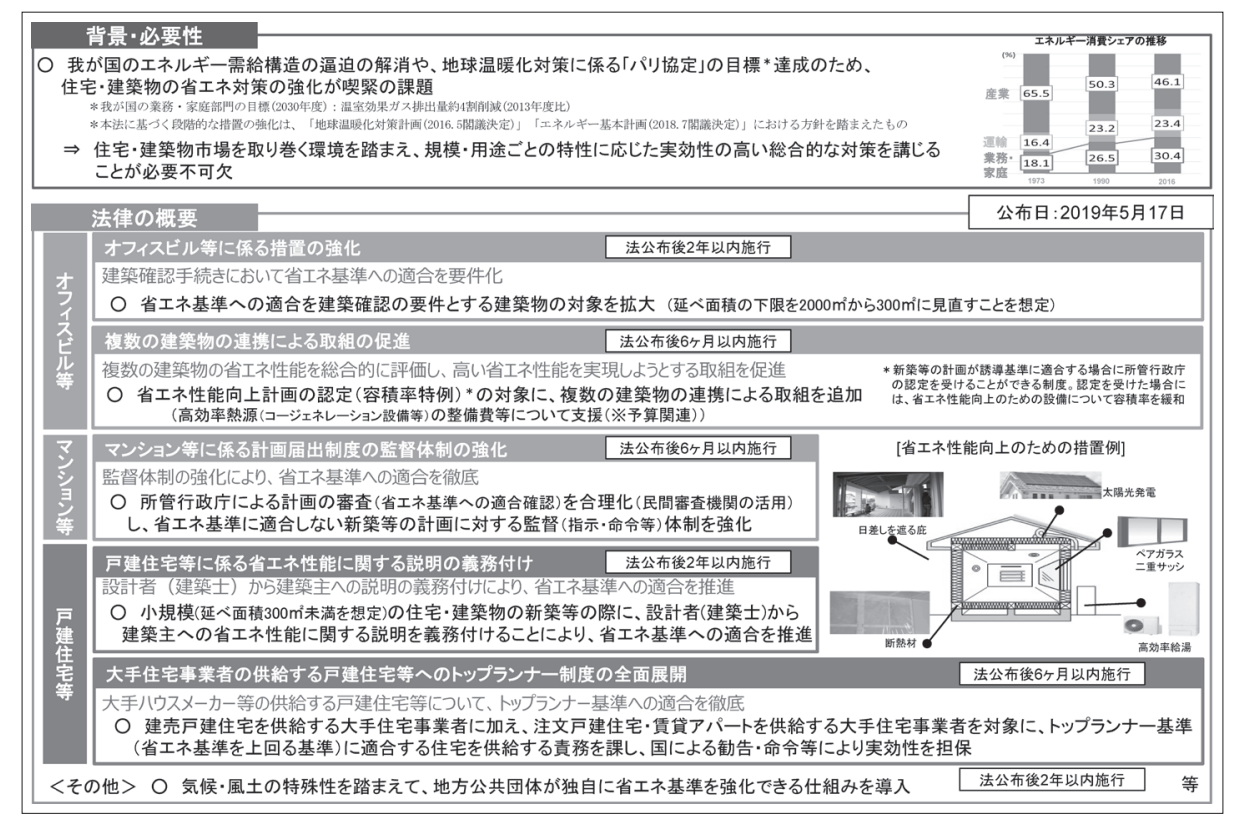

図 4 建築物のエネルギー消費性能の向上に関する法律の一部を改正する法律

\section{【届出制度の執行状況】}

所管行政庁を対象としたアンケート調査によると、省 エネ基準不適合物件への指示を行っていない所管行政庁 は約 8 割存在しています。また、省エネ基準不適合物件 への指示を行う上での課題として、約 7 割の所管行政庁 が省エネ基準への適合審査に係る業務負担が大きいこと を挙げており、約 6 割の所管行政庁が省エネ基準不適合 物件のうち指示の対象とするものの具体的な考元方を定 めることが困難であることを挙げています。

\section{3. 建築物のエネルギー消費性能の向上に 関する法律の一部を改正する法律について}

以上の背景や住宅・建築物の省エネ性能等に係る実態 を踏まえて、

(1)中規模の建築物の適合義務制度の対象への追加

(2)大規模・中規模の住宅に係る届出義務制度の監督体 制の強化

(3)注文戸建住宅及び賃貸アパートの住宅トップラン ナー制度の対象への追加

(4)小規模の住宅・建築物における建築士から建築主へ の説明義務制度の創設

(5)複数建築物連携型プロジェクトの容積率特例制度の 対象への追加

等の措置を総合的に講じることを内容とした「建築物の エネルギー消費性能の向上に関する法律の一部を改正す る法律」(本法律) が本年 5 月17日に公布されています。 (図 4 ) なお、上記の法改正事項の (2)、(3)及び5)につい ては、本法律の公布後 6 ケ月以内の施行を予定しており、 (1)及び(4)については、本法律の公布後 2 年以内の施行を 予定しています。以下、本法律の具体的な内容について
詳述します。

\section{【中规模の建築物の適合義務制度の対象への追加】}

中規模建築物については、

・省エネ基準への適合率が 9 割程度の水準に達してお り、円滑に適合義務化を進められると考えられること ・新築件数が比較的少なく、必要となる審査体制が円 滑に整備されると見込まれること

・省エネ基準への適合のための投資に係る効率性が比 較的高いと試算されること

等を総合的に勘案し、適合義務制度の対象に追加するこ ととしています。

\section{【大規模・中規模の住宅に係る届出義務制度の監督体制 の強化】}

現行制度では、大規模・中規模の住宅については、着 工の21日前までに省エネ性能に関する計画書を所管行政 庁に届け出なければならないこととし、所管行政庁は、 その計画が省エネ基準に適合せず必要と認める場合、計 画の変更の指示等を行うことができることとしています。

しかしながら、多くの所管行政庁に打いては、計算書 等のチェックに係る事務負担が大きい等の理由から、不 適合物件に対する計画の変更の指示等を十分に行えてい ません。

このため、民間の審查機関により発行される評価書の 活用により、審査手続きの合理化を進めることとしてい ます。

具体的には、省エネ基準に適合していることを証明す る民間審查機関による評価書（例えば、住宅品質確保法 に基づく住宅性能評価書）を計画に併せて提出する場合 には、評価書のみの確認で審査が可能となることから、 届出期限を現行の「着工の21日前」から最短で「着工の 3 日前」に短縮することとしています。 
また、併せて、届出時に提出する書類についても、こ うした評価書が提出される場合には、大幅に簡素化する こととしています。

こうした事務手続きの合理化により、所管行政庁にお ける計算書等のチェックに係る事務負担を軽減すること が可能となり、これにより生み出される事務能力を、基 準不適合物件への対応の強化につなげていくことを所管 行政庁との連携のもと進めていきたいと考えています。

【注文戸建住宅及び賃貸アパートの住宅トップランナー 制度の対象への追加】

トップランナー制度は、「エネルギーの使用の合理化 等に関する法律」に基づき分野横断的に創設された制度 であり、製品等の省エネ性能の水準に大きな影響力を持 つ大手事業者に対して、先進的な省エネ技術が採用され た製品等の供給を促すために、市場での技術開発の状況 等を踏まえて、高い水準の基準（トップランナー基準） を目標年次を設定のうえ達成することを努力義務として 課す仕組みです。

住宅分野においては、2009年度より、自らが建築主と なり多くの住宅を建築したうえで販売する大手の戸建分 譲住宅事業者を対象に制度が導入され、制度施行後 5 年 目（2013年度）に対象住宅のトップランナー基準への適 合率が96\%に達するなど、省エネ性能の向上に大きな成 果を上げてきました。

現在住宅トップランナー制度の対象とされていない注 文戸建住宅や賃貸アパートを供給する大手住宅事業者は、 自ら建築主とはならないものの、請負契約を結ぶ建築主 に対して、規格化された住宅の建築を提案・受注するこ とを通じて、住宅の省エネ性能の決定に大きな役割を果 たしています。

こうした住宅は、住宅市場の約 6 割を占め、本分野の 大手住宅事業者に対し先進的な省工ネ技術の採用を促す ことは、住宅分野の省エネ性能の向上に大きな効果があ ると考えられることから、本法律においては、住宅トッ プランナー制度の対象に、注文戸建住宅や賃貸アパート を供給する大手住宅事業者を追加することとしています。 【小規模の住宅・建築物における建築士から建築主への 説明義務制度の創設】

小規模の住宅や建築物は、建築に関する専門知識を持 たない個人が建築主であることが多く、住宅・建築物の 省エネ性能に関する建築主の理解の不足が省エネ性能向 上の課題の一つとなっていると考えられます。

一方で、小規模の住宅や建築物は、建築主自身が当該 住宅等の居住者や利用者になることが多く、設計時点に
おける建築主に対する省エネ性能に関する情報の提供が、 省エネ性能向上のきっかけとなるケースも少なくないと 考えられます。

このため、本法律では小規模住宅等を設計する建築士 に対し、

・当該住宅等が省エネ基準に適合するか否か

・適合しない場合には、省エネ性能確保のための措置 を建築主に対して書面をもって説明することを義務付け ることとしています。

\section{【複数建築物連携型プロジェクトの容積率特例制度の 対象への追加】}

省エネ性能向上計画の認定制度は、高い水準の省エネ 性能の住宅や建築物の新築等に係る計画を所管行政庁が 認定した場合に、省エネ性能の確保のために必要となる設 備の設置に必要となる床面積について、容積率算定上の 延べ面積に算入しないことを特例的に認める仕組みです。

一方で、高い水準の省エネ性能を確保するプロジェク トは、近年、複数の建築物のエネルギー供給設備を一つ の建物に集約するものが増加してきています。

現在の省エネ性能向上計画の認定制度は、こうした複 数の建築物が連携したプロジェクトを想定していないた め、容積率の特例が十分に活用できなくなっています。

このため、本法律においては、複数の建築物が連携し たプロジェクトを想定した規定を追加することにより、 プロジェクト全体の計画を認定したうえで容積率の特例 が行える仕組みへと見直すこととしています。

本改正を通じて、複数の建築物が連携して高い省エネ 性能を実現するプロジェクトの促進を罒りたいと考えて います。

\section{4.おわりに}

パリ協定を踏まえた2030年度の中期目標等の達成に向 け、新築の住宅・建築物において実現すべきエネルギー 削減量を達成するために、まずは本法律に盛り込まれた 措置を適確に推進することが重要と考えています。

今後は、本法律に盛り込まれた措置の円滑な施行に向 け、審査者、関連事業者、建築主等が住宅・建築物の省 エネ性能向上の必要性や制度の内容を理解するとともに、 関連事業者が省エネ基準等に習熟するため、説明会の実 施等により、省エネ性能向上の必要性、制度の内容、省 エネ基準等について、積極的な周知徹底に努めてまいり たいと考えています。 